Pamiętnik Literacki 2018, 1, s. 151-165

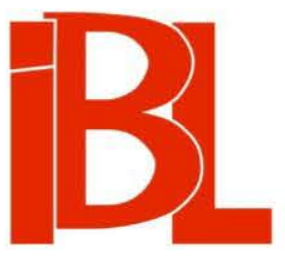

\title{
Poezja paradoksów ontologicznych Stanisława Czerniaka
}

\author{
Paweł Dybel
}


DOI:10.18318/pl.2018.1.8

PAWE⿺ DYBEL Uniwersytet Pedagogiczny, Kraków

POEZJA PARADOKSÓW ONTOLOGICZNYCH STANISŁAWA CZERNIAKA

Na przestrzeni ostatnich kilkunastu lat Stanisław Czerniak zaznaczył wyraźnie swoje odrębne miejsce na mapie rodzimej twórczości poetyckiej. Jego liryka została zresztą już dawno dostrzeżona i entuzjastycznie oceniona przez takich krytyków, jak Ryszard Matuszewski, Wit Jaworski, Julian Kornhauser czy Leszek Szaruga. Dołączyli też później do nich krytycy młodszej generacji - Krzysztof Derdowski, Marek K. Siwiec, Krzysztof Lisowski ${ }^{1}$. Wszyscy oni zgodnie podkreślają, że o oryginalności tej poezji stanowi głównie sposób, w jaki podejmowane są tam różne filozoficzne toposy, wiążące się z historią europejskiej metafizyki, z rysującymi się w niej stanowiskami i zadawanymi pytaniami. Autor wykształcił bowiem w ciagu wielu lat specyficzny rodzaj dyskursu, w którym w formie poetyckiej próbuje uprawiać refleksję filozoficzną.

Osobliwość tego dyskursu nie polega jednak na tym, że do języka poetyckiego wprowadza Czerniak szereg typowych pojęć filozoficznych, ani też, że gra w nim różnymi powszechnie znanymi cytatami $z$ tradycji filozoficznej. Nawiązania do tradycji, nawet jeśli się pojawiają, nigdy nie są bowiem traktowane w sposób dosłowny. Te filozoficzne pojęcia i wypowiedzi ulegają zwykle przewrotnej transformacji, objawiając nieoczekiwanie swoje całkiem nowe sensy. Łączy się to $\mathrm{z}$ faktem, że postawę Czerniaka znamionują zazwyczaj ironiczna przekora i parodia. W rezultacie podniosłe niekiedy znaczenie pewnych kluczowych pojęć i popularnych powiedzeń filozoficznych zostaje zdemaskowane. Ujawniane jest niejako ich miękkie podbrzusze, w wyniku czego wywracane sa na nice.

Czerniak, który sam jest historykiem filozofii specjalizującym się w XX-wiecznych koncepcjach antropologii filozoficznej (Max Scheler, Helmuth Plessner, Arnold Gehlen i inni), ma świadomość tej zasadniczej zmiany statusu pojęć filozoficznych, kiedy stają się one elementem dyskursu poetyckiego. Taka zmiana stanowi zresztą podstawowy warunek tego, aby owe pojęcia zaczęły „żyć” w obrębie wiersza albo zaczęły być tu traktowane jako narzędzia poetyckie, nie filozoficzne. Inaczej całe przedsięwzięcie poetyckie utraciłoby rację bytu. Poezja sprowadzałaby się do nieudolnego naśladowania filozofii. Autor pisze o tym w eseju, który jest swoistym

1 Zbiór wypowiedzi krytycznych na temat tej poezji przynosi książka Antropologia podmiotu lirycznego. (Wokót „Nagiego ŻE” Stanisława Czerniaka) (Red. K. D e r d ow s ki. Toruń 2012). 
autokomentarzem do jego poezji. Wychodzi w nim od zakreślenia różnicy między filozofią a nauką:

różni się [filozofia] od nauk empirycznych doktrynotwórczą rolą pojęć. O ile w nauce rozwój teorii odbywa się równolegle do przeobrażeń systemów twierdzeń konfrontowanych w procedurach kwalifikacyjnych z empiria, o tyle doktryny filozoficzne rozbudowywane sa - w procesie przypominającym biologiczne pączkowanie lub rozrost - wokół paradygmatycznych pojęć podstawowych. Przykłady: „życie”, „osoba”, „egzystencja”. Pojęcia są całostkami kognitywnymi szczególnie nasyconymi elementami intuicyjnymi, umożliwiając niejako źródłowy ogląd pewnej sytuacji poznawczej, która otwiera jakieś ważne filozoficzne pytanie. Twierdzenia i odwołujące się do nich ciagi argumentacyjne pojawiają się dopiero wtórnie jako próby racjonalizacji owych pierwotnych intuicji filozoficznych [...]. [s. 150 $]^{2}$

Według Czerniaka pojęcia używane w filozofii i jej twierdzenia mają całkiem inny status niż pojęcia i twierdzenia naukowe. O wiarygodności i wartości poznawczej twierdzeń oraz pojęć w nauce stanowi w ostatecznym rozrachunku ich empiryczna weryfikacja, natomiast w filozofii pojęcia rozwija się i rozbudowuje zgodnie $\mathrm{z}$ ich własna pojęciową istotą. Wynika to stąd, że związki między nimi są spekulatywne - maja swoje oparcie w ich czysto intelektualnej, pojęciowej postaci, która nie poddaje się empirycznej weryfikacji.

Na tym spekulatywnym charakterze pojęć filozoficznych opierała się już grecka metafizyka, która aż po nasze czasy - wbrew temu, co sądzą filozofowie analityczni - znajduje w filozofii europejskiej swe twórcze kontynuacje. Specyfika tego typu filozoficznej refleksji zasadza się na rozwijaniu przez nią związków między pojęciami na sposób intuicyjny. Tylko w taki sposób bowiem dają się zgłębić relacje między nimi i może zostać uzyskany określony rodzaj poznania.

Spekulatywny status pojęć $\mathrm{w}$ filozofii zbliża ją z kolei do poezji, której język zakorzeniony jest w tym samym „metafizycznym” podłożu pewnych fundamentalnych idei i pojęć, nie poddającym się empirycznej weryfikacji. Tak Czerniak próbuje wytłumaczyć głębokie pokrewieństwo filozofii i poezji, biorąc za punkt odniesienia własny dyskurs poetycki:

Moja poezja krąży wokół kilkunastu pojęć, takich m.in. jak „samowiedza”, „wnętrze”, „sen”, „ciało”, „Bóg”, „wiersz”, „korekta”, „kontyngencja”, „nicość” czy „zwierzę”. Każde z tych pojęć ma określone konotacje filozoficzne, ale podmioty liryczne tej poezji nie konstruuja parafilozoficznego rusztowania, które wiązałoby je w sposób jednoznaczny ze sobą. Nie chodzi tu o to, że ta poezja pragnie być metaforycznym wstępem do jakiegoś spójnego, zbudowanego na podstawie owych pojęć stanowiska filozoficznego. Przeciwnie - mamy tu do czynienia raczej z laboratoryjnym tyglem, w którym pojawiaja się one w różnych kontekstach znaczeniowych i w różnej metaforycznej oprawie. Są surowymi kryształami obrabianymi pod kątem ich możliwego użytku filozoficznego. Szlifuje się je poetycko po to, by wydobyć ich wieloznaczność i w akcie poetyckiej intuicji usytuować je w nowych, niejako „eksperymentalnych” ramach semantycznych. [s. 151]

Jeśli zatem poezja jest głęboko spokrewniona $\mathrm{z}$ metafizyką $\mathrm{z}$ racji operowania pojęciami o podobnym spekulatywnym statusie, które dają się rozwinąć w oparciu o intuicję, nie znaczy to, że stanowi tylko „przedsionek” czy „wstęp” do refleksji

2 Wszystkie cytaty pochodzą z wyd.: S. C z e rn i a k, Iskra buntu. Nowa Wieś nad Drwęcą 2016. Przy przytoczeniach ze szkicu Prasens a kondycja ludzka. Liryka jako laboratorium filozoficzne podaję stronice, przy cytatach $z$ wierszy - ich tytuły. 
filozoficznej. Pole poetyckiego doświadczenia języka przecina się wprawdzie z polem pojęć filozoficznych, ale jako „laboratoryjny tygiel” zachowuje ono zarazem wobec filozofii autonomię i innego typu wartość poznawczą.

Nie wyklucza to, że poezja może być źródłem inspiracji dla filozofa. Tkwiący u jej podłoża specyficzny sposób doświadczania rzeczywistości i wyrażanie tego doświadczenia w wierszach pozwala bowiem, poprzez zderzanie kluczowych pojęć filozoficznych $z$ „konkretem” pewnych sytuacji, rzeczy, osób, wydobyć $z$ tych pojęć nowe aspekty znaczeniowe. Każą one wówczas filozofowi postawić całkiem nowe pytania, wymagają swego refleksyjnego „przepracowania” i rozwinięcia w języku pojęciowym.

Ten szczególnie intymny związek poezji z filozofią towarzyszy zresztą tej ostatniej od zarania. Żywioł poetyckości odnajdujemy w niektórych formułach filozoficznych Talesa, Heraklita, nie mówiąc już o prawdziwie poetyckich wizjach Platona, w których starał się on wyrazić najbardziej złożone zjawiska otaczającego go świata. W filozofii współczesnej głębokie pokrewieństwo obu tych dziedzin daje o sobie znać w twórczości Nietzschego i Heideggera, Derrida zaś podejmuje próbę „dekonstrukcji” wszelkich sztywnych przedziałów między dyskursem filozofii a dyskursem literatury. Ale z prawdziwie poetyckimi metaforami możemy się spotkać również u filozofów, którzy nie podejmowali w odrębny, „metodyczny” sposób tej kwestii - u Hegla, Schopenhauera, Schelera, Plessnera, a nawet u samego Wittgensteina.

O filozoficzności poezji Czerniaka stanowi przede wszystkim to, że nawiązując do klasycznych toposów europejskiej metafizyki autor stara się w dyskusji z nimi budować własną filozofię poetycka poprzez nadanie im nowych znaczeń. Jednym z podstawowych wyznaczników tej osobliwej filozofii jest konfrontowanie w poetyckim języku tych toposów z różnymi wewnątrzświatowymi wydarzeniami, zazwyczaj należącymi do sfery potocznego życia, z ludzkimi zachowaniami, klasycznymi scenami i motywami znanymi $z$ tradycji europejskiej kultury, ze szczególnymi własnościami zwierząt, ludzi, rzeczy itd. W takim postępowaniu chodzi o to, aby owe toposy ując $z$ nietypowej perspektywy, która pozwala spojrzeć na nie innymi oczyma. W tym sensie poezja jest dla Czerniaka osobliwym laboratorium, w którym eksperymentuje on nieustannie $z$ ludźmi, zwierzętami i rzeczami. Poddaje tropy filozoficzne - żeby posłużyć się metaforycznym określeniem Bacona - różnym „torturom”, umiejscawiając je w nieoczekiwanych sytuacjach, w których ujawniają one swe nowe aspekty.

Tworzywem - i obiektem - tych eksperymentów nie jest jednak samo doświadczenie, tak jak sie je pojmuje w naukach empirycznych, ale zawsze doświadczenie zapośredniczone przez język: nietypowe zestawienia poszczególnych słów, zwrotów, fraz, pozwalające dostrzec w potocznych z pozoru, codziennych wydarzeniach coś głęboko paradoksalnego, a niekiedy wręcz absurdalnego. Laboratorium poetyckie jest bowiem przede wszystkim laboratorium języka. To w nim i poprzez niego dokonuje się poetyckie otwarcie na świat, rozstrzyga się doświadczenie bytu i niebytu, istnienia i nieistnienia, życia i śmierci.

W języku konstytuuje się specyficzna ontologia tego świata, którą można by 
nazwać ontologia paradoksu. Składają się na nią wskazane przez Czerniaka różnego typu antynomie tkwiące $\mathrm{w}$ bycie, dostrzegane jedynie przez przenikliwe oko poety. Możliwe jest to dzięki odwróceniu dominującej na co dzień perspektywy ujęcia, w której wzrok patrzącego koncentruje się na tym, co jest, czyli na różnych dostępnych naocznie postaciach i przejawach bytu. Tymczasem tutaj na plan pierwszy wysuwa się, paradoksalnie, doświadczenie tego, czego nie ma, konfrontowanie siebie - i czytelnika $-\mathrm{z}$ różnymi postaciami niebytu. $\mathrm{W}$ rezultacie niebyt dominuje tu nad bytem, nieistnienie nad istnieniem, śmierć nad życiem. Czerniak penetruje poetycko różne oblicza tej dominacji, naruszając w swoich wierszach utrwalony zwyczajowo obraz świata.

Ale w równie radykalny sposób jego język poetycki różni się od typowego dyskursu filozoficznego. W wierszach Czerniak robi użytek ze swego rodzaju niezwykłej własności tego języka: pozwala mu grać w sposób znacznie bardziej swobodny, niż ma to miejsce w dyskursie filozoficznym, pewnymi pojęciami, które tradycyjnie mają tu kluczowe znaczenie. Weźmy choćby tak fundamentalny problem filozoficzny jak zagadnienie czasu, który od Arystotelesa, poprzez św. Augustyna, po Heideggera i Husserla, doczekał się niezwykle rozbudowanych i wyrafinowanych ujęć filozoficznych. W poezji Czerniaka staje się on obiektem wysublimowanej gry słownej:

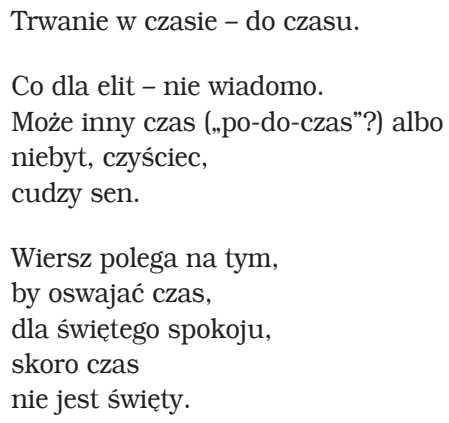

(WiersZ X)

Słowny kalambur pierwszego wersu odsłania paradoksalność ludzkiego doświadczenia czasu, które ma miejsce tylko „do czasu”. Staje się podstawą do pojawienia się w następnym fragmencie kolejnego kalamburu. Jest nim neologizm „po-do-czas”, czyli inny czas, który rozpoczyna się po śmierci - po czasie „do” i któremu człowiek w swoich fantazjach próbuje nadać szczególny status. Wyobraża go sobie jako jakiś „inny czas”, przeznaczony tylko dla wybranych, który właściwy jest „istnieniu” w niebycie, w czyśćcu, we śnie boga. Sa to jednak wszystko kulturowe iluzje wspierane przez koncepcje religijne czasu „świętego”, w którym człowiek egzystuje po śmierci.

Tym iluzorycznym, podniosłym wyobrażeniom czasu Czerniak przeciwstawia własne - zdawałoby się, bardzo trywialne - doświadczenie poetyckie czasu, gdy pisanie wierszy stanowi jego oswajanie „dla świętego spokoju”. Rzecz jednak w tym, że tylko taki minimalistyczny program doświadczenia czasu jest realistyczny. A zarazem najbliższy fenomenowi czasu, tak jak doświadcza sie go na co dzień. Czasu bowiem nie da się przezwyciężyć, przeciwstawiając jego ziemskiemu doświadczeniu jakieś wyjątkowe, inne istnienie „po” czasie. Zamiast tego należy zaakceptować jego 
przemijanie, kierunek, „do” którego zmierza. Tylko w ten sposób można go „oswoić” i uzyskać upragniony wewnętrzny „święty” spokój, Heideggerowska „Gelassenheit", w obliczu tego, co czas ze sobą niesie.

Tak pojęty minimalizm poetycki w doświadczaniu czasu, który odwołuje się do poczucia zdrowego rozsądku, znamionuje podejście Czerniaka do różnych aspektów rzeczywistości. Mogłoby się zdawać, że jest to postawa konformistyczna, w istocie jednak tkwi w niej swoisty heroizm. Idzie za nią programowe odrzucenie wszelkich mitów, jakie w kulturze człowiek tworzy na swój temat i bez jakich nie może się obyć. W tym wypadku sa to mity na temat czasu, za których pomoca człowiek chce dla siebie oswoić okrutne przeznaczenie, jakie ze sobą niesie dla niego czas.

Innego typu mity to te, które człowiek tworzy odnośnie do swojego nazwiska:

$$
\begin{aligned}
& \text { Nazywam się von Habsburg. } \\
& \text { A ja się nie nazywam. } \\
& \text { Nic się we mnie nie nazywa: } \\
& \text { głowa, ręka, ucho. } \\
& \text { Co najwyżej przynależy: } \\
& \text { do Ziemi, Drogi Mlecznej. } \\
& \text { Jeśli już, to tam są właśnie } \\
& \text { jakieś księgi metrykalne. } \\
& \text { (Droga mleczna) }
\end{aligned}
$$

Mity tworzone w kulturze przez człowieka na własny temat znajdują swój szczególnie wymowny wyraz w podniosłym kulcie, jakim darzy on niektóre nazwiska, nadając im status „arystokratycznych”. Tym wyróżnionym przez siebie symbolicznym formom identyfikacji człowiek gotów jest przypisywać wyjątkową wartość, podczas gdy w istocie są one wyłącznie iluzoryczną wierzchnią warstwą, pod którą skrywa się faktyczny, skończony wymiar ludzkiego bytu, związany z podległością człowieka prawom Ziemi - prawom rozpadu ciała i duszy, prawom śmierci. Ostatecznie tylko ten wymiar się liczy, jedyne bowiem, co z nas pozostaje, to drobiny materii, które stają się częścią kosmosu.

W innych wierszach odwracanie potocznej perspektywy spojrzenia na różne sprawy tego świata dotyczy już bezpośrednio doświadczenia nicości. Tyle że, rzecz ciekawa, inaczej niż w filozofiach, w których eksplorowaniu tego doświadczenia towarzyszył podniosły egzystencjalny patos, Czerniak na swój sposób je trywializuje. W Litości np. „radzi” nicości, aby zamiast czekać w obliczu napierających na nią Himalajów martwych „ciał, / narządów i poglądów, / naczyń i nieruchomości” zdobyła się, wiedziona instynktem samozachowawczym, na ucieczkę. Pozostałości tych rzeczy bowiem: popiół, pył ceglany, butwiejący papier, „plamią czystą i nieskazitelną / strukturę niebytu".

Nie istnieje zatem coś takiego, jak rodząca trwogę i drżenie „czysta” nicość Kierkegaarda, Sartre’a, Heideggera. Zawsze jest ona „zabrudzona” pyłem ziemskiej skończoności, co też ją na swój sposób paraliżuje. Sprawia to, że przepojona litością 
wobec napierających na nią martwych szczątków ludzkiego życia i ludzkiej kultury nieruchomieje i staje się bezradna. Ale też właśnie na tym zasadza się prawdziwy tragizm relacji między nicością a ludzkim bytem, którego nędzne pozostałości przytłaczają ją swoim ogromem. Nie zaś na doświadczaniu nicości jako „czystej” negacji bytu, czegoś, co jest w stosunku do niego absolutnie inne.

Próba poetyckiego opisania odniesienia ludzkiego bytu od strony nicości owocuje zatem swoistą degradacją tej ostatniej. Okazuje się, że ma ona również słabości. „Zabrudzona” różnymi ziemskimi pyłami, popiołem, nie jest już tylko tą nicością, jakiej doświadczali i jaką opisywali w swoich dyskursach wspomniani filozofowie. W wierszu Wycieczka nicość daje nazwę osobliwemu parkowi rozrywki, oferującemu rozmaite formy jej doświadczania. Ale także i tutaj owo doświadczanie jest pozbawione niesamowitej, metafizycznej aury, jaką na ogół się z nią kojarzy. Zamiast tego wszystko wydaje się tu jedynie parodią analogicznych „ziemskich” doświadczeń:

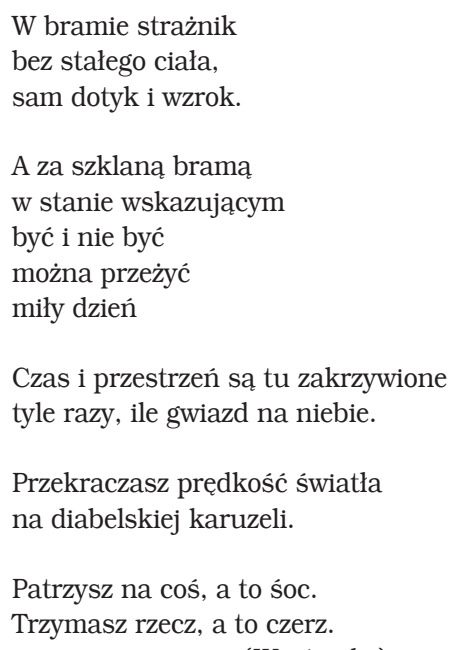

(Wycieczka)

Rozrywka oferowana podmiotowi lirycznemu przez park „Nicość” nie ma w sobie niczego z odczucia powagi i grozy, z jakim doświadczenie nicości zwykło kojarzyć się filozofom, którzy opisują je z perspektywy skończonego ziemskiego bytu. Wszystko staje się w tym parku tylko zabawną karykatura zwykłych ziemskich doświadczeń. Ale wraz z tym nowe znaczenie zyskują również owe ziemskie doświadczenia. Okazuje się bowiem, że nicość nie stanowi dla nich żadnej alternatywy; doświadczana w parku rozrywki, stała się elementem potocznego doświadczenia. Uległa swego rodzaju ontologicznej degradacji.

Wynika stąd jednak, że dominacja nicości nad bytem jest w poezji Czerniaka pozorna. Bierze się ona wyłącznie z przekornie odwróconej perspektywy spojrzenia na byt, w której punktem wyjścia jest nicość doświadczana na poziomie potocznym. Właśnie to osobliwe ontologiczne przesunięcie sprawia, że poetyckie doświadczenie nicości zostaje pozbawione egzystencjalnej powagi i grozy. Ba, w jego wyniku nicość staje się wręcz komiczna i groteskowa.

Ta przewrotna strategia wyzwalania poprzez „grę słów” takich znaczeń w kluczowych pojęciach filozoficznych, o jakie byśmy ich nigdy nie podejrzewali, jest 
specyficznym wyróżnikiem warsztatu poetyckiego Czerniaka. W jego wierszach są one nieustannie umieszczane w nietypowych dla nich kontekstach sytuacji wziętych $\mathrm{z}$ życia codziennego i w rezultacie parodiowane na rozmaite sposoby.

Pozwala to Czerniakowi spojrzeć na klasyczne pojęcia i problemy filozoficzne z perspektywy ironicznego dystansu. Tak jak ma to np. miejsce w Doświadczeniu, w którym sparodiowane i opatrzone znakiem zapytania zostaje odwołujące się do „empirii” stanowisko filozoficzne tkwiące u podłoża nowoczesnego przyrodoznawstwa. W tym stanowisku to, co „empirycznie” dane, traktuje się jako niezawodna podstawę wszelkiego poznania naukowego, tymczasem według autora Iskry buntu:

Nie ma szczebli bytu i poznania,

jest samo doświadczenie, postrzępione i rozmyte.

Tak, to się wydarzyło, tam byłem i widziałem, przedtem, potem, mieszają się porządki.

(Doświadczenie)

Polemiczny przekaz poetycki w tym wierszu jest jasny: nawet „widzenie” jakiegoś wydarzenia, bezpośrednia przy nim obecność, nie daje gwarancji jego obiektywnego opisu. Po pierwsze bowiem, owo doświadczenie jest „postrzępione i rozmyte", widzimy zwykle tylko jego fragment. Po drugie zaś - jego opis zostaje dokonany z perspektywy jakiegoś „potem”, a wraz z nią w sposób nieunikniony pojawiają się nowe elementy, zmieniające pierwotny ogląd. Doświadczenie czegoś przybiera zawsze postać wyobrażenia sobie tego czegoś w określonej postaci i nigdy nie mamy pewności, czy „się przytrafia wyobraźni naprawdę?” (Doświadczenie).

$\mathrm{W}$ innym wierszu $\mathrm{z}$ kolei świat doświadczany jest przez podmiot z perspektywy „odlepienia” od niego, czyli skrajnego zeń wyobcowania i osamotnienia, które nadchodzi wraz ze starczym zniedołężnieniem, kiedy „nic się już nie klei” (Odlepienie). Wtedy dopiero dostrzegamy, że do tej pory byliśmy „przylepieni” do świata, nie widząc różnicy między nim a sobą, rozkoszując się wszystkim tym, co on nam oferuje. Teraz zaś, pozostawieni samym sobie w naszym „odlepieniu”: „dziwimy się światu, że jest w kocie i w Godocie, / a na nas nie czeka" (Odlepienie).

Świat bowiem, całość bytu, którą uosabia, jest we wszelkich swoich postaciach wobec faktu naszego istnienia lub nieistnienia - obojętny. Nie liczymy się dla niego zupełnie w naszym jednostkowym istnieniu. Nawet pamięć bliskich, a niekiedy i całych pokoleń, po ich śmierci prędzej czy później się zaciera. Znikamy bezpowrotnie i z czasem nikt nie odczuwa po nas braku. Życie toczy się dalej, jakby nigdy nic. Może też właśnie dlatego jedyną skuteczną strategią wobec poczucia nieuchronności śmierci i faktu, że po latach nikt nas nie będzie pamiętał, jest „żyć jak gdyby NIGDY / NIC" (Moda), a nie próbować histerycznie coś robić, aby temu przeciwdziałać. Buntując się, stajemy się Don Kichotami walczącymi bezskutecznie $z$ wiatrakami czasu.

To doświadczenie obojętności bytu wobec ludzkiego istnienia (lub nieistnienia) zawarte jest również w wierszu Wiewiórka, który nawiązuje do słynnej początkowej sceny z filmu Bergmana. Oto na pniu zwalonego wichurą drzewa, które śmiertelnie przygniotło człowieka, pojawia się wiewiórka zawzięcie poszukująca dla siebie orzechów. Natomiast to, że przed chwila w tym miejscu rozegrała się jakaś ludzka tragedia, zupełnie jej nie interesuje. Ba, w jej świecie nie ma w ogóle miejsca na tę 
tragedię. W tym też sensie ludzkie istnienie lub nieistnienie nic dla wiewiórki „nie znaczy". A jest tak dlatego, że:

\author{
[...] Wiewiórki \\ istnieją, bo istnieją. \\ Mogłoby ich nie być, \\ $Z$ jakichś przyczyn sa. \\ Nie zdarzyły się w przyrodzie, żeby, \\ Lecz dlatego że.
}

(Wiewiórka)

Nie ma żadnej teleologii w bycie nakierowanej na człowieka jako jego zwieńczenie. Byt istnieje, bo istnieje, a nie dlatego, że został przez Kogoś stworzony w jakimś celu. Czerniak w tym poglądzie wydaje się bliski rozumieniu bytu właściwemu filozofii greckiej, nie znającej pojęcia stworzenia świata z nicości, jak też teleologicznego pojęcia dziejów, nastawionych na powrót człowieka do Boga.

Wiersz ten stanowi zarazem wymowne poświadczenie ontologii poety, którą wypowiedział on już w swoim wcześniejszym zbiorku, tytułując go Nagie ŻE. Byt, istnienie czegokolwiek możemy tylko potwierdzić jako fakt i je uznać. Spekulowanie na temat przyczyny i celu bytu jest jałowe. Prowadzi donikąd.

Nie zmienia to jednak w niczym tego, że ów fakt doświadczany jest przez człowieka jako trudny do zniesienia paradoks. Niełatwo mu bowiem zaakceptować, że to, co on sam doświadcza jako dotykająca go tragedię, której nadaje symboliczny wymiar, może z punktu widzenia przyrodniczego bytu nic nie znaczyć. Na eksponowaniu takich paradoksów związanych ze specyficznie ludzkim stosunkiem do świata, do spraw bytu i niebytu, istnienia i nieistnienia, życia i śmierci ześrodkowana jest cała poezja Czerniaka. Znamionuje ją to, że egzystencjalne kwestie bytu i niebytu, istnienia i nieistnienia, życia i śmierci stały się tu elementem gry słownej, w której wydobywa się ich groteskowy wymiar i absurd.

W tej grze nie chodzi jednak o sama językową „zabawę” owymi pojęciami, o sprowadzenie poezji do zwykłego kalamburu, z którego - poza czysto językowym efektem - nic nie wynika. Wręcz przeciwnie, jest to gra całkowicie serio, w której pod maską słownego dowcipu i ironii skrywają się najzupełniej „poważne” egzystencjalne kwestie. Jest to gra przesycona głębokim tragizmem egzystencjalnym, który ewokowane w niej paradoksy słowne tylko pozornie neutralizują i „oswajaja”.

Śledząc gry poetyckie, jakie proponuje ta twórczość, wkraczamy zatem w obszar spraw jak najbardziej „poważnych”, spraw życia i śmierci. Tak się dzieje w otwierającym Iskrę buntu znakomitym wierszu Piramida, nad którym warto się dłużej zatrzymać.

Piramida jest tu metaforą wszelkich ludzkich starań, aby zabezpieczyć własne życie przed rozpadem i śmiercią. Okazuje się jednak, że, podobnie jak to było z piramidami, które mimo wyrafinowanych zabezpieczeń zostały doszczętnie splądrowane przez złodziei, nie ma sposobu, aby ochronić ludzkie życie przed ingerencją intruzów $\mathrm{z}$ zewnątrz. Wynika to $\mathrm{z}$ wpisanej w nie nieuchronności śmierci, konieczności przejścia w stan niebytu czy nieistnienia.

Dlatego wszelkiego rodzaju „schrony”, które człowiek buduje dla siebie za życia, tworząc mity na swój temat, jak też na temat swego bytu po śmierci, narażone są od wewnątrz na rozpad. W tym kontekście idea wznoszenia faraonom grobowców 
$\mathrm{w}$ formie piramid $\mathrm{w}$ celu zapewnienia im $\mathrm{w}$ ich śnie wiecznym własnego „szlaku do nieba" była $z$ góry skazana na porażkę. Fakt, że niemal wszystkie te grobowce splądrowali złodzieje, a dzisiaj spokój snu faraonów zakłócają tłumy wścibskich turystów, stanowi tylko zewnętrzne potwierdzenie zagrożenia, które tkwi w skazaniu ludzkiego życia na śmierć. Dlatego w piramidzie ludzkiego życia:

Złodziejem jest każdy szmer, wszystko może być turystą, nawet własny byt, którego nie ma.

(Piramida)

Największe niebezpieczeństwo dla życia nadchodzi zatem od strony samego życia, a nie od strony innych. Ci ostatni - złodzieje, turyści - tylko poświadczają realność tego zagrożenia, przed którym nie ma ucieczki. Ostatecznie sposób odniesienia ludzkiego życia do śmierci ma w sobie coś z paradoksu. Wydaje się nam, że na życiu możemy budować coś trwałego, podczas gdy w nim samym zawarta jest jego negacja, przejście w niebyt, w nieistnienie.

Podobny motyw szukania przez człowieka - jak się okazuje, iluzorycznych zabezpieczeń przed różnymi przykrymi niespodziankami, jakie moga go spotkać ze strony życia, pojawia się w wierszu Kompensacja. Jest on parodia obsesyjnego dążenia człowieka do budowania własnego poczucia pewności na ubezpieczaniu się od wszystkiego, co może życie mu przynieść, w nadziei, że w taki sposób uniknie bolesnej konfrontacji $z$ surowymi prawami określającymi jego egzystencję i przyrodniczy byt. Człowiek ten to typowy mieszczanin-kołtun, któremu wydaje się, że wszystko na świecie da się kupić, również istnienie Boga. A nawet jeśli to, przed czym się zabezpieczył, nie spełni nadziei, to powstałą stąd stratę zrekompensuja inni:

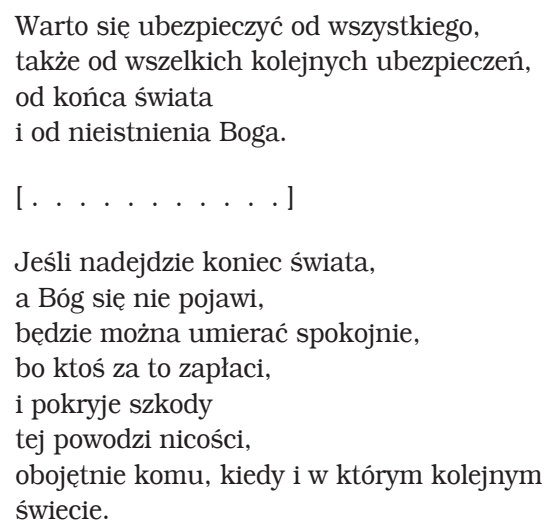

(Kompensacja)

Takiemu człowiekowi wydaje się, że przed wszelkimi kwestiami egzystencjalnymi można zabezpieczyć się tak samo, jak zabezpieczamy się przed pożarem mieszkania, kradzieżą, wypadkiem drogowym. Kiedy więc one się faktycznie wydarzaja, wówczas zapewniona w ten sposób „rekompensata” sprawia, że wolno nam je traktować jako nie mające $z$ nami nic wspólnego.

Wyczuwalna w tym wierszu ironia to w rzeczywistości zjadliwa krytyka współczesnej mentalności mieszczańskiej, w której wszystko przelicza się na pieniądze. 
Nawet możliwy koniec świata i istnienie Boga. Ubezpieczenie się od tego to typowy współczesny „zakład”, będący w zasadzie parodią i karykaturą słynnego zakładu Pascala.

Nazwanie poezji Czerniaka poezja paradoksu ontologicznego pozwala - o czym krytyka już pisała - wskazać na jej różnorakie związki z liryką niektórych poetów pokolenia '56: Herberta, Szymborskiej, Białoszewskiego, Karpowicza. No i może jeszcze debiutującego wcześniej Różewicza. W poezji tych autorów bowiem również operowanie na różne sposoby paradoksem językowym było kluczowym wyznacznikiem ich stylu. Ale nasuwa się jeszcze inna analogia. Mam na myśli twórczość Stanisława Jerzego Leca uprawianą w zwięzłej formie językowych kalamburów.

Liryka Czerniaka sytuuje się gdzieś między tymi dwoma biegunami poetyckości. Znajdziemy wiersze, których lakoniczna puenta $z$ efektem komizmu kojarzy się ze sposobem jezzykowego konstruowania „złotych myśli” przez Leca, jak też utwory bardziej językowo rozbudowane i „rozrzedzone”, przypominające styl poezji Herberta czy Szymborskiej. Tyle że zarazem w wierszach autora Iskry buntu owo operowanie logiką paradoksu przybiera szczególną postać. Wiąże się to ze wspomnianą dominacja „negatywnej” strony bytu (niebyt, nieistnienie, śmierć) nad „pozytywną" (byt, istnienie, życie). Dlatego podmiot tych wierszy często sytuuje się na granicy tego, co jest, i tego, czego nie ma, życia i śmierci. Tak jak w wierszu Moda, gdzie świadomość, że „nie będzie mnie”, każe przerażonemu tym podmiotowi obmyślać różne strategie poradzenia sobie z owym „przykrym” faktem, który kiedyś niechybnie nastąpi. I okazuje się, że pewne strategie przedstawiają się dzisiaj dość komicznie, uchodzą wręcz za „niemodne”. Ale też śmieszna wydaje się strategia człowieka pierwotnego, który chcąc siebie uwiecznić, gotów był „namalować coś na skale”.

W wierszu Bez siebie z kolei podmiot rozważa ewentualność „istnienia bez siebie", a zatem osiagnięcie dziwnego stanu, w którym traci on tożsamość siebie. Wtedy też jego miejsce jako świadomego siebie ,ja” zajmuje „rzeczywistość” jako „nowy nastrój istnienia / bez siebie”. W rzeczywistości jednak to istnienie bez siebie jest istnieniem w stanie śmierci - więc istnieniem niemożliwym, w którym „nowy nastrój" to brak nastroju. Brak samego siebie.

Odwrócenie perspektywy patrzenia na świat jest jednak, jak się okazuje, nie tylko kwestią arbitralnej decyzji poety, ale również - jeśli nie przede wszystkim efektem tego, co się stało ze współczesną kulturą. Znamionuje ją bowiem to, że, wbrew pozorom, to nie człowiek roztacza w niej coraz większą władzę nad rzeczami. Przeciwnie, to rzeczy zaczynają nad nim panować. W wierszu Rzeczy mówi się np. o tym, że nie jest tak, iż ludzie podporządkowują sobie rzeczy, lecz odwrotnie: „Rzeczy mają na wyposażeniu ludzi [...]”, ba, „Ludzie służą dzielnie rzeczom w boju, / przydaja się do drobnych korekt". Czym są rzeczy? Wiersz na to pytanie nie odpowiada, tylko przytacza kolejne sytuacje świadczące o władzy rzeczy nad ludźmi. Rzeczy bowiem:

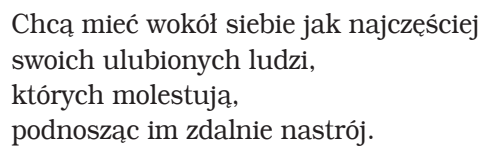




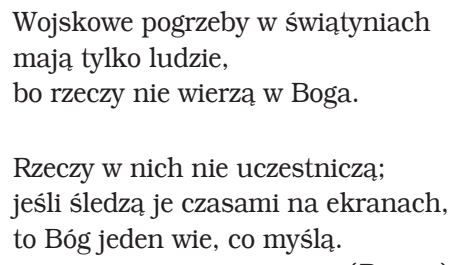

(Rzeczy)

„Rzeczy” to zatem świat internetu, smartfonów, tabletów, niewidocznych kamer, ekranów śledzących nasz każdy ruch, reklam. To one, sprawnie zarządzane z ukrycia, wnikają w najintymniejsze przestrzenie naszego życia prywatnego, kształtuja nasze potrzeby, nasz obraz świata, nasze poglądy, manipulują nami itd. Władza tego typu rzeczy nad ludzkimi jednostkami przybrała dzisiaj charakter totalny i całkowicie anonimowy, symbolizując ewolucję naszej kultury, w której, paradoksalnie, stajemy się coraz bardziej zależni od naszych produktów.

Być może zatem - w związku z podobną wszechwładzą rzeczy nad nami - doświadczamy dzisiaj końca „epoki / zadawania pytań, trwającej już co najmniej od czasów Sokratesa" (Historia). Obecnie niemal nikt -

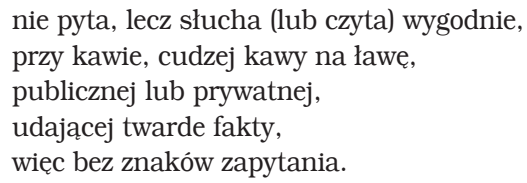

(Historia)

Inny symptomatyczny przejaw specyfiki naszych czasów to gorączkowe szukanie jakiejś alternatywy dla przygnębiającej nudy życia, ta jednak jest paradoksalnie tylko efektem napędzanej przez media pogoni za „mocnymi” przeżyciami i sensacją:

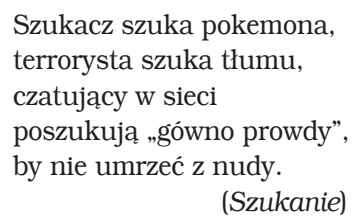

Człowiek współczesności szuka obiektów pozornych, podsuniętych jego wyobraźni przez świat internetowego ekranu. Oddaje to wymownie stopień jego wyobcowania $\mathrm{z}$ rzeczywistości, w wyniku czego odwrócony został porządek przyczyn i skutków, źródeł i celów. W rezultacie człowiek zatracił fundamentalny instynkt obronny. Jest teraz jak miasto, które:

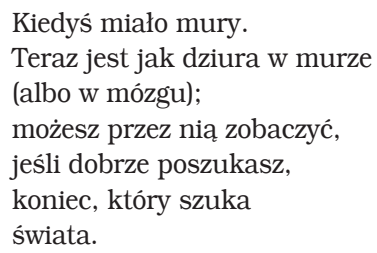


Koniec, który szuka świata, to, innymi słowy, koniec, który nie może się w nim rozpoznać, gdyż wszyscy szukają jedynie tego, co jest końcem pozornym czy pozorem końca. A więc szukają takiego „końca”, który niczego nie rozwiązuje i nie wypełnia, tylko domaga się swego ponownego powtórzenia. Jest końcem-dziurą nie do zalepienia i nie do zatkania.

Jak już pisałem, na doświadczaniu siebie i świata od strony negatywnej: strony nieistnienia, niebytu, rozpadu wszystkiego, co otacza podmiot, i rozpadu jego samego, zasadza się tropienie przez Czerniaka w poetyckim języku różnych postaci paradoksu ontologicznego, który określa ludzkie istnienie i istnienie świata. To celowe, metodyczne wymazywanie siebie, kiedy „nic nie ma znaczenia” (Lewitacja), wszelkie zaś próby „wzięcia się w garść” wyglądają tragikomicznie. Towarzyszy temu ciagłe ironizowanie na temat siebie, obnażanie schematyzmów własnego potocznego myślenia o świecie, eksponowanie ukrytych i niekiedy wręcz wstydliwych aspektów doświadczania siebie. Takim wstydliwym aspektem, przepojonym głęboką intymnością - i brutalnością zarazem - jest również sam akt pisania wiersza, w którym ustanowiona zostaje szczególna, przepełniona swoistym erotyzmem, bliskość podmiotu piszącego wobec języka:

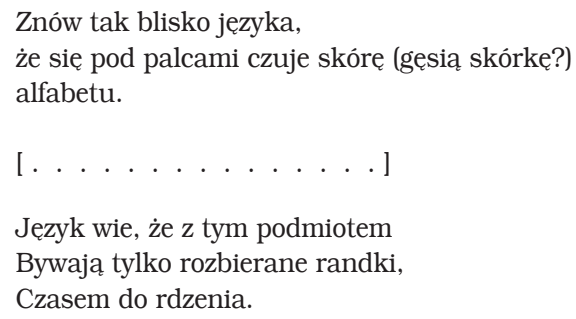

(Wiersz XIV)

Podmiot ten zachowuje się wobec języka niczym kapłan-sadysta, dla którego akt pisania ma w sobie coś z okrutnego aktu rytualnego, brutalnego gwałtu, kiedy najpierw należy w języku-ofierze wywołać trwogę, przerazić. Dopiero wówczas może on zacząc „celebrować język / swego bożka” (Wiersz XIV), a więc - kreować w nim własna poetycką wizję świata.

W tym ujęciu akt pisania wiersza ma w sobie coś z inscenizacji o quasi-religijnej wymowie. To wszakże tylko jedna z postaci gry, jaką Czerniak prowadzi z językiem. Poezja ostatecznie jest gra w języku, która jeśli nawet odsyła do spraw najzupełniej poważnych, o tragicznym wręcz wydźwięku - jak sprawy bytu i niebytu, życia i śmierci - to zarazem je w pewnym sensie neutralizuje, uczy dystansu do nich, każe ironizować na ich temat. Poezja to jakby ciągłe odnajdywanie własnego miejsca w świecie poprzez język, w którym ewokowane są różne strony paradoksu ontologicznego przenikającego ludzkie istnienie i istnienie świata. W rezultacie już samo ich nazwanie pozwala je na swój sposób „oswoić”, wyzwolić z traumatycznego wydźwięku i grozy. To ciagłe zaklinanie rzeczywistości słowami, ale nie poprzez nadawanie jej cudownego, magicznego charakteru, lecz bardziej prozaicznie i przyziemnie. To uczenie się trwania w życiu poprzez poetyckie tropienie i nazywanie przenikających je antynomii i sprzeczności, jego wystawiania w słowach, niejako od wewnątrz, na niebyt i nieistnienie. 
Poezja ostatecznie rodzi się na poziomie dnia codziennego. Kiedy nachodzi, podmiot jest wydarzeniem samoistnym, bioracym się $z$ niczego, niespodziewanym darem niebios, którego genealogia pozostaje niezgłębiona:

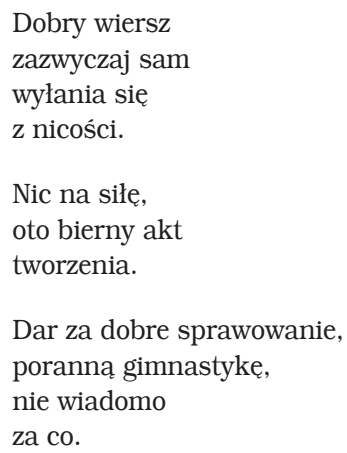

(Wiersz VIII)

W utworze Ars poetica VI akt narodzin wiersza ujęty został z perspektywy przepływu „fal mózgowych”, jako ich przypadkowy efekt:

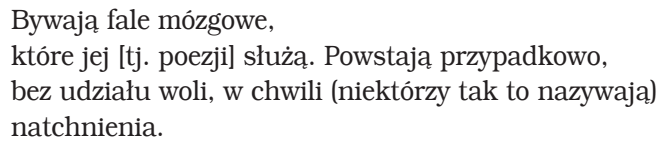

(Ars poetica VI)

Tę interpretację aktu kreacji wiersza można odnieść do Heideggerowskiej „Gelassenheit”, czyli przyjęcia przez filozofa luźnej, pełnej akceptacji postawy wobec bytu oraz gotowości na to wszystko, co nadejdzie od jego strony. Najbardziej odkrywcze myśli i poznania zjawiają się bowiem samoistnie, nie przymuszone żadnym oczekiwaniem czy żmudnym i wyczerpującym wysiłkiem intelektualnym.

W innym utworze $z$ kolei Czerniak wskazuje na organiczne powiązanie wiersza z ciałem poety:

Podmiot liryczny miał zamilknać

bezpowrotnie, ale okazało się, że jego nosiciel ma jeszcze rezerwy witalne, jakieś zdrowe tkanki gotowe do wcielenia się w wiersz.

To ryzykowna gra, bo może kiedyś zaistnieć potrzeba od-cielenia, powrotu wiersza do ciała.

(Nadczłowiek)

W tym ujęciu wiersz to bezpośrednie, biologiczne wręcz, przedłużenie ciała poety. Dlatego po śmierci tego ostatniego grozi mu „od-cielenie”, powrót tam, skąd został wywiedziony. Tyle że:

podmiot liryczny to przecież zawadiaka,

utracjusz i ryzykant udający nadczłowieka 
Nietzschego, który twierdził: własne ciało

jest materią woli

mocy.

(Nadczłowiek)

Ostatecznie zatem podmiot liryczny swoją „awanturnicza” egzystencję wywodzi nie tylko z ciała poety, ale również z „woli mocy”, której ciało jako materia podlega. $\mathrm{W}$ tym sensie genealogia owego podmiotu sięga poza ciało. Dlatego wiersz może zacząc „udawać nadczłowieka”, uniezależniając się w jakiejś mierze od ciała. Podmiot liryczny egzystuje $\mathrm{w}$ końcu $\mathrm{w}$ jezzyku, prowadzac $\mathrm{w}$ nim niebezpieczne gry słowne, które w każdej chwili mogą skończyć się porażką. W grach tych, nie mając nic do stracenia, stawia on nieustannie na szalę całego siebie, ryzykując w nich wszystkim, samym swoim istnieniem.

W ogóle wiersz jako „nowe wydarzenie / na granicy / ciała i języka” (Wiersz IX) odbiega od potocznych gier językowych, w których uczestniczymy na co dzień. Nachodzi on poetę często w czasie snu i wtedy poeta, budząc się w nocy, wstaje, aby go zapisać:

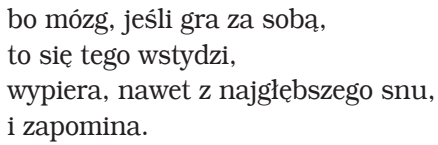

(Wiersz IX)

Materia wiersza jest ulotna niczym marzenie senne, gdyż, podobnie jak w nim, mózg gra tu nie tyle „ze”, co „za” sobą. Prowadzi on tu grę w języku jakby na drugiej, ukrytej przed światłem świadomości, scenie jaźni. Gra ta dotyczy przy tym spraw głęboko intymnych i często absurdalnych w swej wymowie, ludzki mózg wstydzi się ich i robi wszystko, aby o nich jak najszybciej zapomnieć.

Nasuwa się tu nieodparcie skojarzenie z Freudem, który marzenie senne uznał za główne źródło wiedzy o ludzkiej psychice. Ujawnia się w nim bowiem całe bogactwo wypartych myśli śniącego podmiotu, dając wgląd w jego najskrytsze „problemy", do których na jawie nie chce się on przed soba przyznać. Podobnie dla Czerniaka absurdalne gry wyobrażeń, jakie mózg śniącego prowadzi „za” soba $\mathrm{w}$ czasie snu, sa głęboko spokrewnione $\mathrm{z}$ grami, jakie poeta prowadzi w języku, pisząc wiersz. Właśnie dlatego, że dotyczą spraw, które na co dzień podlegają wyparciu, stanowią one nieocenione źródło prawdy poetyckiej.

Nic dziwnego, że pisanie wierszy to dla Czerniaka rodzaj wyrafinowanej autoterapii, w której, nazywając rzeczy po imieniu, zapisując w słowach „to, co jest”, oswaja on w jakiejś mierze lęki nachodzące go od strony własnego ciała, rzeczywistości, innych. Eksperymentuje poetycko ze swoim ciałem, jaźnią i rzeczami, każąc im lewitować, spoczywać w piramidzie, odcieleśniać się, być „bez siebie”, przenosić się do parku o imieniu „Nicość”. Ostatecznie gra poetycka to szczególna gra, w której:

Niby gra się słowami,

lecz byt włącza się do gry.

Jest jak drugi fortepian

w koncercie Bacha. 
A to już jest inna gra.

Byt gra $z$ toba

W niebyt,

Niemal bez słów.

(Wiersz XIV)

Nie jest to więc tylko gra słów, choć wszystko dzieje się tu w słowach i przez słowa. To zarazem gra w milczeniu $z$ bytem $w$ niebyt, w której podmiot liryczny jest tylko bezwolnym obiektem (bo to byt $z$ nim gra, a nie on $z$ bytem), stawkę zaś stanowi jego istnienie. $\mathrm{W}$ owej grze też jest już z góry przegrany.

Na tym właśnie polega paradoks poezji. Na pozór sa to tylko słowa, w ich tle jednak pobrzmiewa bezgłośnie drugi fortepian bytu, który poezji tej nadaje kierunek $\mathrm{i}$ ton. Ton tragiczny. W jego milczącej grze rozstrzygają się rzeczy ostateczne.

Abstract

PAWE⿺ DYBEL Pedagogical University, Cracow

\section{STANISŁAW CZERNIAK'S POETRY OF ONTOLOGICAL PARADOXES}

The author of the article points at an original mode in which Stanisław Czerniak in his poetry approaches an array of classical philosophical tropes. He starts his paper with a reflection about how, in general, the relation between philosophy and poetry should be captured, as their discourses on the one hand show mutual affinity and overlap in many points, yet on the other hand, they are differentiated in their treatment of linguistic material. While philosophers accentuate its abstract, conceptual side, poets emphasise the representative aspect of the concrete, "think" mainly in the picture built in the words of a poem, and not in terms of notion. Next, as based on selected Czerniak poems' interpretations and their fragments, the paper demonstrates the particular way in which he poetically deals with the key philosophical notions of time, nothingness, hierarchy of entities, culture-nature relationship, God's existence, phenomenon of death etc. A characteristic trait of Czerniak's treatment of those issues is displaying ontological paradoxes which reside in them. Much attention in the paper is also paid to such Czerniak's pieces in which the poet is critical about the various myths and illusory images that mark the thought of today's Internet and smartphone society. In such interpretations, special attention is given to the linguistic side of Czerniak's poems in which the poet performs sophisticated plays on words. 